\title{
鳥マラリアの研究
}

\section{[4] 日本產野鳥の血液內寄生虫の自然感染狀態}

\author{
加納六部术村マ \\ 傳染病研究所街生動物研究室（主任: 佐々學助教授）
}

[受付：2月 28 日, 1950 年]

私共は日本素野鳥を材料として，鳥マラリアの研究 を行つたため，相賞の數の鳥を报う機會をえ，かつマ ラリア研究の材料として用いた垛合，自然感染が重大 な問題となるのでこれら鳥類の血液內寄生蟲の自然 感染狀態を調菒した。本邦におけるこの方面の報告は 小川, 上垣, 峰, 有騐, 登倉の嘫氏によつてなされて いる。しかしこれらはいずれも西日本で行われたもの で，東日本における報击は殆んどない。私共の材料は 全部閵東地方で入手したもので，調查方法は生鳥の翼

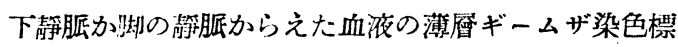
本の鏡榆によつた。たよ゙しごく少數の銃獵によつたも のは，死亡淔後心㶓からえた血液を用いた。な颃々 の血液內寄生蟲の分類と形態に關しては, 次の報告に りずる。なお今日まで日本で報告された野鳥の血液內 寄生蟲の宿主の表を揭げ參考に供すナる(第 2 表)。

\section{成}

\section{䋘}

5 日 18 科 49 種 310 犲の日本座鳥類（關東でえた もの）を檢し， 2 日7科 24 種 71 牙に血液内寄生蟲 の存在を認めた。その分布狀態は第 1 表の如くである 本調查により見出し之た血液內俞生䖵は，Trypanosoma, Haemoproteus, Plasmodium, Leucocytozoon,

Microfilaria であつた。

\section{Trypanosoma}

5 種万旸の島に見られ，いず狄洤科のもので，血 夜中に扎け西數は極めて少かつた。奇主鳥はシメ，マ ヒワ, ベニマシコ, オウマシコ,アトリの 5 種で, こ の中マヒワ, オウマシコ, アトリの 3 種は Trypanosoma の宿主として末記録でせる。ベニマシュのもの は非常に大形で明かな縱殺が見られた。

\section{Haemoproteus}

8 湩 16 犻に見られ，いずれもかなり商度の感染で まつた。塞主息はキジパ、, イカル, シメ, カワラヒ ワ, アオジ, カシラダカ, クロジオオルリで, その 中キジバト，アオジ，カシラダカ，クロジの 4 種は

Rokuro, KANO. and Mari, KIMURA:t Studies on the bird malaria (4). Natural infection of blood parasites in Japanese wild birds. Jupan. J. Bact.,5 (2) : 103-104 1950, (Te Institute for Intectious Diseases, the University of Tokyo, Tokyo.)
Haemoproteus の宿主として未記錄である。クロジ のものは色素粒が大で桿狀をなし，オウルリでは，核 をとりまいていて，色素粒は圓形で大きい。シメ，カ ワラヒワ等のものは核をとりまくことは稀で, 色素粒 も小さい。

\section{Plasmodium}

7 種 10 㶷に見られ，とくにッグミ科のものに膺く 分布していた。宿主鳥はべニマシコ, ヒヨドリ, キビ タキ, クロッグミ, アカハラ, シロハラ, ツグミで, ヒョドリ以外の宿主は皆末記錄である。Plasmodiu$m$ は 4 種見られ, ベニマシコには Pl.circumflexum ヒョドリには, $P l$. rouxi と $P l$. vaughani キビタキ には Pl. nucleophilum の記載に一致するもの, その ほかのッグミ科のものには, Pl.vaughani が見出さ た。Pl. vaughani!はかなり廣く分布し, 特にッグミ 科のものに多かつた、しかし生殖體の圓形の Pl. cat hemelium p pl. relictum は今日までの報告には非常 に多いにもかかわらず，今包の調查では，1 例も遭遇 しなかつた。

\section{Leucocytozoon.}

最も多種にわたり，かつ多數の鳥に寄生しているも ので, 17 種 35 旸に見られた。宿主鳥は, イカル, シ メ, コカワラヒワ,マヒワ, ベニマシコ, ウッ, オウマ シコ,アトリ, スズメ, アオジ, カシラダカ, シジウ カラ, ヒガラ, クロッグミ, アカハラ, シロ ハラ, カ ケスで, その中, イカル, ベニマシコ, オウスシコ, アオジ, カシラダカ, シジウカラ, ヒガラ, クロッグ ミ,アカハラの 9 種が末記錄である。これらの Leu一 cocytozoon は宿主鳥により，それぞれ特有の形態をな し，被寄生血球の核を兩側に引き伸し，紀錘形をなす もの，核が原蟲を取卷くもの核が一侧に熙排されてい るもの等が見られた。シジウカラ科に屬するシジウカ ラ, ヒガラの 2 種のものは核が兩側に引伸ばされて, 紡錘形をしている。

\section{Microfilaria}

雀科の 4 種, シメ, イカル, クロジ, ホホジロに見 られ, 我國では比較的少いものと思われる。今迄には 
ホホジロのも,のを登倉登氏の 1942 年の報告があるだ けである。すなわちホホジロ以外の 3 種は末記錄で, ホホジロとイカルのものは非常に似ているが，他の鳥 の Microfilaria は形態㵔しく異り, 別種と考えら れる。

\section{考 案}

私共は 1948，1949 年の 2 笝年にわたり, 關東地方 で大手した鳥類の檢血を行い, 流血內寄生蟲の自然感 染狀態の 1 部を觀察することができた。結局 5 日 18

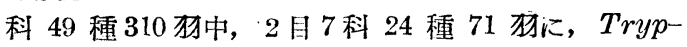
anosoma, Haemoproteus, Plasmodium Leucocytozoon, Microfilaria を男た。これらの戌績は野鳥を用 いる喠々の顀驗に際して，大に參考資料となると信ず る。例えば Pl. relictum を用いて，抗マラリア劑の 檢定を行う場合等は, 我々の實驗では, これら自然感 染の鳥は健康鳥と, その感受性は殆えど變らず, かつ Pl. relictum '類似の寄生體が存在しなかつた篇, そ の鑑別も容易たはむつたが，やはり極力避けるべきで ある。また逆にこれららの自然感染鳥を利用して，種々 の望驗檢定等を行いらる。例之ば Pl. circumflexum 等はこの目的に用いらる。その他野鳥の保護, 驅除, 家禽飼養等の見地から多，參考資料となることと思; 終りに臨み, 鳥類捕萑に關し絶大の御援助を睗つた林 野聽獵政調查課の黑田長禮博士, 葛精一, 白井邦应, 小柳和助，三酉冬哃の渚氏に深謝致します。

\section{文献}

1）小川政修：緒方正規教授在職 25 年記念呮賀論交 集, 1909.

2) Ogawa, M.: Arch. Protist. Jena., 24, 119 126 1911.

3）峰㨁次郎：日本望雀に寄生する条種「へモ゚゚ロテ ウス」及び「ロイコチトッオン」の知見及び鑑別に 關する生物學的触驗, 京京醫學會倠誌, $27,(13)$; 23, 大正 2 (1913).

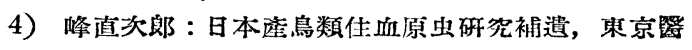
學會雜誌, 28, ( 8), 1, 大 3 (1914).

5) 小川政修: 佳血原虫論, 大 7 (1918).

6) Yorke \& Maplestone: The Nematode Parasite of Vertebrates. 1926.

7) Wenyon, C.M.: Protozoology., 1926.

8) Og wa, M. \& Uegaki, J.: Arch. Protest. Jena., 57.

9) Brumpt, E.: Précis de Parasitologie., 1927.

10) Uegaki, J.: Untersuchung über die Blutprotozooen von Vogeln der Sïdsee. Arch. f. Protist.,
$7274 \sim 90,1930$.

11）阔田落迪：「トリパノゾーマ」の生物學的研究,

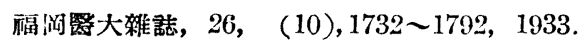

12）有馬閔：「プロテオゾーマ」の㮔別に關する研

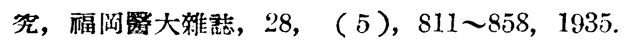

13) Coatney, 'G.R.: A Note on Trypanozoma nicroti. J. Parasit., 21, 455 456, 1935.

14) Coatney, G.R.: A Cheek-List and Host-Index of Genı: Hąemoprotelıs. J. Parasit., 22,88 105, 1939.

15) Wood, F.1). \& Wood, S.F.: Oscurrence of $\mathrm{H}_{-}$ aematozoa in some California Mird; \& MTammal; J. Parasit., 23,197-2:1,1937.

16) Coatney, (i.R.: Cataloz and Hoit-Index of Genus Leucocytozoon. J. Parasit., 23,202,1937.

17) Herms, W.B. \& al. Blōod Paravite; of California Bird $\div$ J. Parasit., 25,511 512,1939.

18) Hewitt, R.: Studie; on Blond Protơoa obtained from Mexican Wild Mircls. J. Para it., 26,287 $\sim 99,1940$.

20) Hewitt" R.: Bird Malaria 1940.

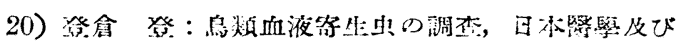
健康保險, 3220, 438, 1941.

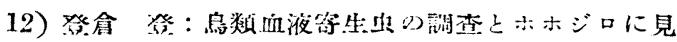

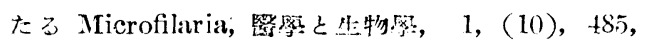
1942.

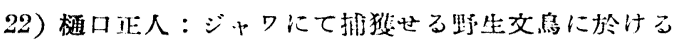

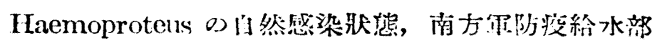
策報, 闪, 53, 1, 1943 .

23) Wood, S.F. \& Herman, C.II.: The Occurrence of Blood Parasites in Mirds from Southwestern U.S., J. Parasit., 29, 187 196, 1943.

24) Richard, R. Kudo, D. Sc.: I'rotozooloyy, 278, 1947.

25) M.Nevert-Lemaire: Traité de Protozoologie medicale et vétérinaire, 246.

62) A Special Committee of the Ornithological Society of Japan: A Hand-List of the JapaneseBir ds., 1942 .

72) Audubon, J.J.: The Jirds of America. 
第 1 衰 日本産鳥颣の血液內兾生虫自然感染狀態

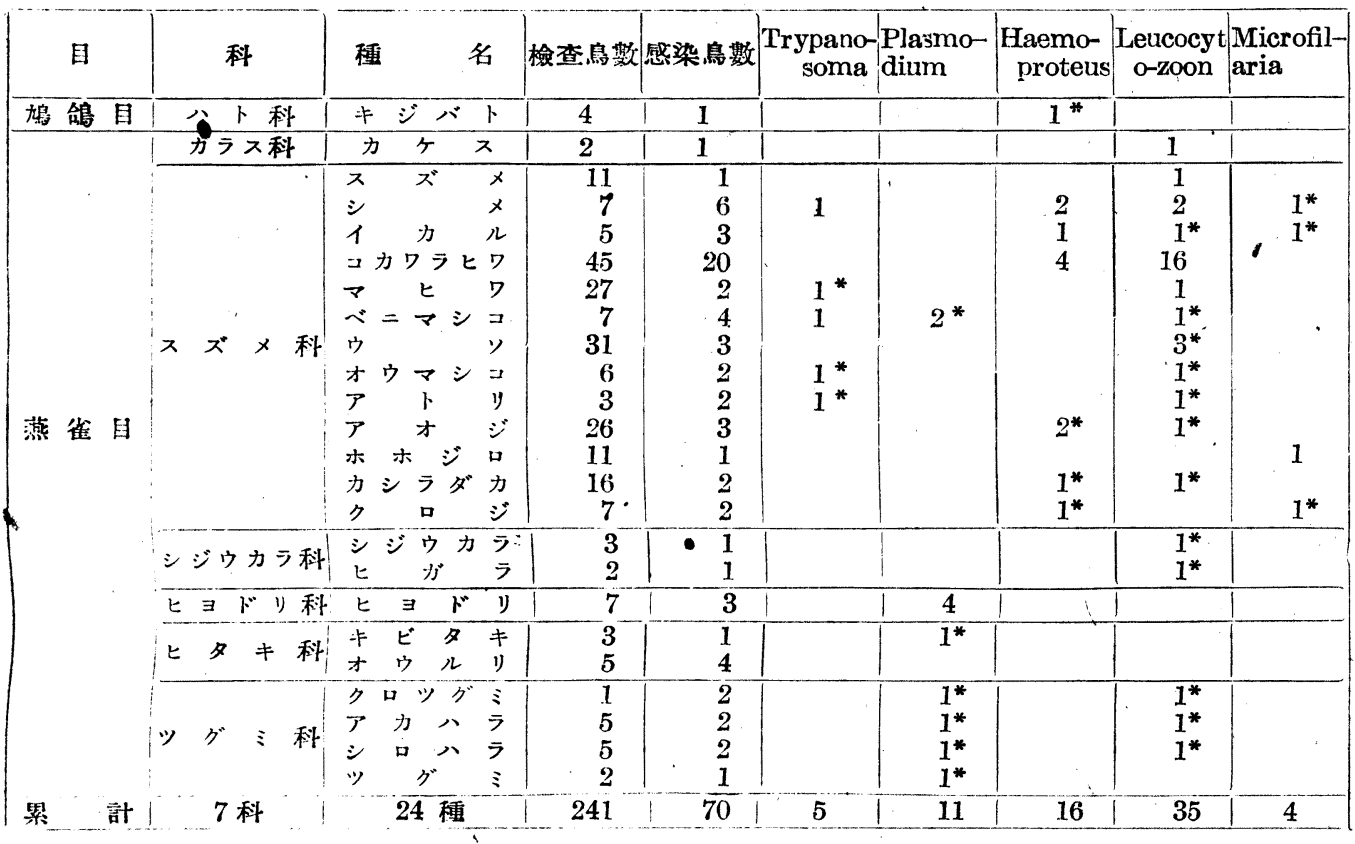

註：學名は紙面の都合上省略するので，日本鳥學會發行の A Hand-List”of the Japanese Birds.,(1942) を参照されたい。

*印は未記錄原虫及び末記錄宿主鳥。

以上は自然朢染の認められた種だけで，份自然感染の見られなかつた種は次の如くである。（） 內の數字は被检鳥數。

キジ科: ニワトリ(5), コジュケイ(1), キジ(4), ウズラ(1), 雄岉科: アヒル(9), ハト科：ドバト（2） オウム科: 七キセイインコ(1), キンパラ科: ジウシマッ(3), プンチョウ(1), シロキンカチヨウ(1) ススメ科: カナリヤ(7), オウカワラヒワ(9), イスカ(3), ノジュ(4), ヒバリ科：ヒバリ(1), メジロ 科: メジロ(3), シジウカラ科: ヤマガラ(2), モズ科: モズ(4), ムクドリ科: ムクドリ(1), レンジヤ ク科：ヒレンジ+ク(2), ウグイス科：ウグイス(1), ツグミ科：マミチヤジナイ(1), ママドリ(2), コルリ(1), イワヒバリ科：カヤクグリ(2).

第 2 表 日本産鳥顛住血客生虫自然鸿染記錄

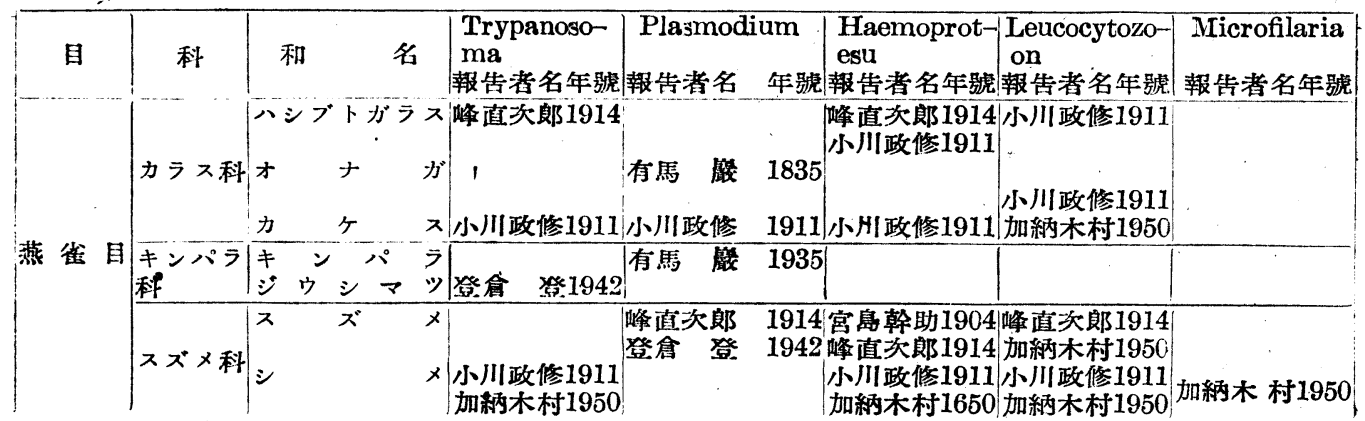




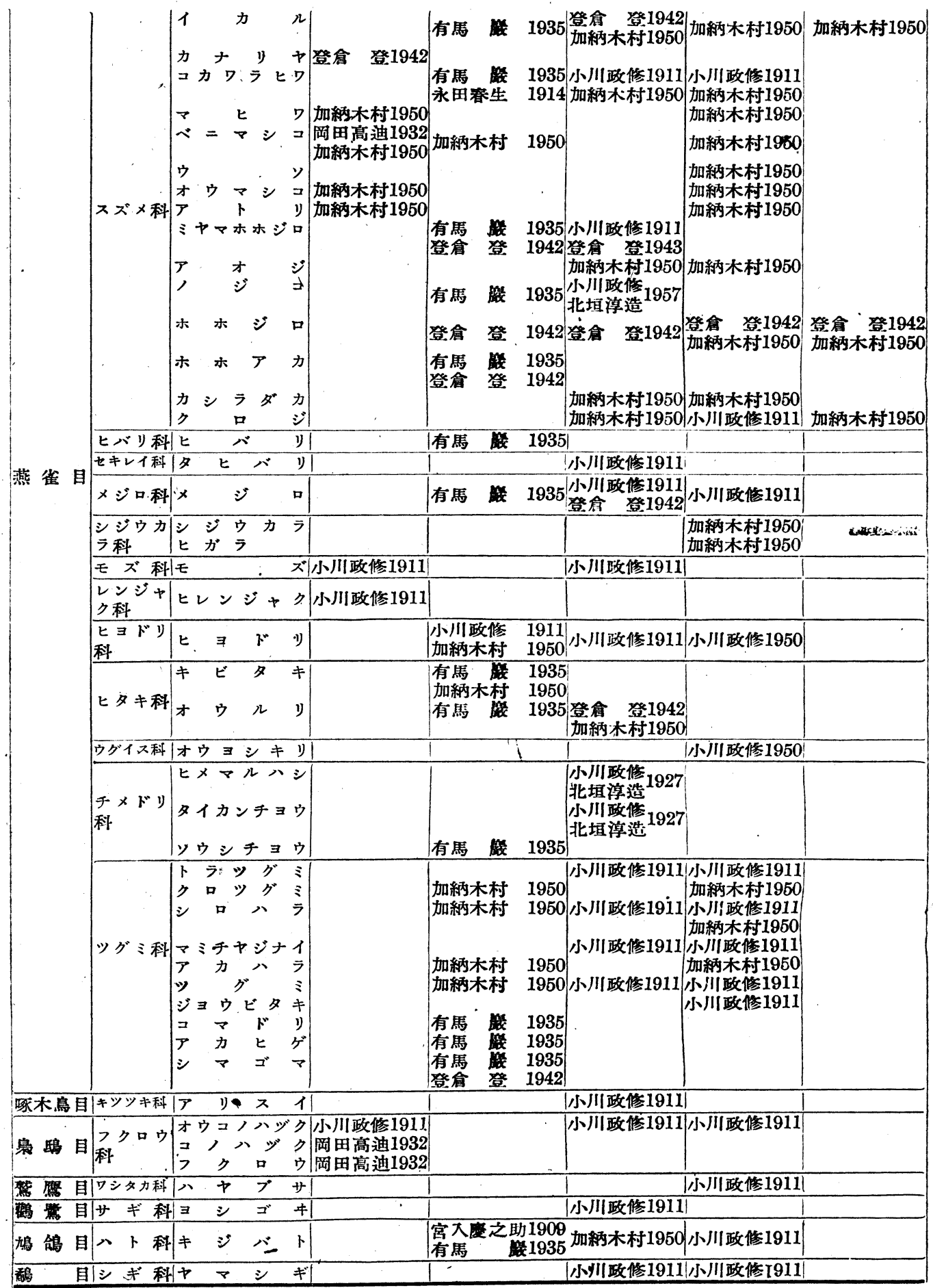

